Gut, 1975, 16, 528-532

\title{
A search for a transmissible agent in Crohn's disease
}

\author{
RICHARD V. HEATLEY, P. M. BOLTON, E. OWEN, W. JONES WILLIAMS, AND
} L. E. HUGHES

From the Departments of Surgery and Pathology, Welsh National School of Medicine, Cardiff

SUMMARY Controversy exists as to whether a transmissible agent is responsible for Crohn's disease. Previous reports have suggested that sarcoid-like granulomas can develop in animals following inoculation of homogenates derived from bowel affected by Crohn's disease. This study involved the injection of Crohn's tissue homogenates into experimental animals under a variety of conditions which might be expected to favour the demonstration of such an agent.

Homogenates have been inoculated into the ileum of rats, mice, and rabbits and also given into the lumen of the gastrointestinal tract in the rat. In addition, homogenates have been inoculated into ileum and footpads of rats which have previously been rendered lymphoedematous by surgical interruption of the draining lymphatics. Bowel homogenates from a total of 17 patients with Crohn's disease have been injected into 91 experimental animals. No macroscopic or microscopic changes indicative of Crohn's disease were detected.

Thus study does not support the suggestion that a transmissible agent is present in Crohn's disease.

A great deal of interest has been aroused by reports suggesting that a transmissible agent may be present in Crohn's disease. Mitchell and Rees (1970) reported their findings following the inoculation of mouse footpads with bowel homogenates obtained from a patient with Crohn's disease. Sarcoid-like granulomas were found in 13 of 56 footpads examined, whereas with control homogenates granulomas were identified in only one of 153 footpad specimens. Also, two mice developed granulomas in the terminal ileum and one had granulomas in the liver. Similar findings have been reported by Taub and Siltzbach (1972) who found that five of 16 mice developed granulomas following footpad injection with Crohn's tissue homogenates. Subsequently, Cave, Mitchell, Kane, and Brooke (1973) extended this work by injecting frozen homogenates of Crohn's bowel into the ileum of three rabbits. Macroscopic changes in the terminal ileum were reported and granulomas were seen in each of the animals on histological examination.

Our previous attempts to confirm and extend this work have proved negative (Bolton, Owen, Heatley, Jones Williams, and Hughes, 1973, 1974). Following

Received for publication 9 May 1975. the inoculation of tissue homogenates from 10 patients with Crohn's disease in a study involving 334 experimental animals (rats, mice, and guinea pigs), we were unable to find any sarcoid-like granulomas in the footpad or the terminal ileum of any animal. A further study has now been undertaken to investigate certain circumstances which might favour the demonstration of any such agent.

Lymphatic obstruction has been implicated in the pathogenesis of Crohn's disease (Reichert and Mathes, 1936; Hadfield, 1939; Warren and Sommers, 1954; Amman and Bockus, 1961) and lymphoedematous tissues are known to be particularly susceptible to infection (Drinker, Fields, and Homans, 1934). We have inoculated homogenates of Crohn's tissue into footpads and ileums of rats following surgical interruption of the draining lymphatic pathways.

As we did not use rabbits in our earlier experiments, ileal inoculation of Crohn's homogenates in rabbits has been performed in a similar manner to that described by Cave et al (1973). Parallel inoculation of homogenates into the ileum of rats and mice has been carried out.

Finally, results of experiments using the leucocyte migration inhibition test have suggested that an antigen related to Crohn's disease may be present in 
the intestinal lumen (Dykes, 1970). We have attempted to show by repeated intragastric instillation of a homogenate of Crohn's tissue into rats if any agent in Crohn's tissue could be transmitted by this route.

\section{Material and Methods}

\section{TISSUE PREPARATION}

Specimens of diseased bowel were obtained from eight additional patients to those previously reported (Bolton et al, 1973) who were undergoing intestinal resection for Crohn's disease. Typical clinical and pathological features of Crohn's disease were present in all cases, and all of the eight exhibited sarcoid-like granulomas histologically.

Control specimens were obtained from the normal ileal and colonic margins of three right hemicolectomy specimens with localized colonic carcinomas. Samples of all the tissues to be homogenized were examined histologically and confirmed the absence of disease.

Segments of full thickness of bowel wall were removed from the fresh surgical specimen, and homogenates'prepared and examined bacteriologically as previously described (Bolton et al, 1973).

The Crohn's homogenates used for intragastric administration to rats were prepared by the same technique from bowel specimens of a further nine patients with Crohn's disease, frozen in ampoules, maintained at $-70^{\circ} \mathrm{C}$ and pooled before use.

\section{ANIMAL INOCULATIONS}

The animals used (table I) were rats (Wistar), mice (TO strain), and rabbits (New Zealand whites).

Footpad inoculations of $0.03 \mathrm{ml}$ of homogenate were made into hind footpads of mice and rats using a 30 gauge needle.

Inoculation of homogenates into the bowel wall was performed in rats, mice, and rabbits. Under pentobarbitone and ether anaesthesia, the animals' abdominal skin was shaved, cleaned with hairremoving cream and washed with soap and water. Following the application of a sterile adhesive skin

\begin{tabular}{lllr}
\hline Species & $\begin{array}{l}\text { Route of Administration } \\
\text { of Homogenate }\end{array}$ & $\begin{array}{l}\text { Regional } \\
\text { Lymphatic } \\
\text { Obstruction }\end{array}$ & No. \\
\hline Mice & Ileal injection & - & 17 \\
Rats & Ileal injection & - & 18 \\
Rabbits & Ileal injection & - & 7 \\
Rats & Footpad injection & + & 19 \\
Rats & Ileal injection & + & 14 \\
Rats & Oral & - & 16 \\
\hline
\end{tabular}

Table I Experimental animals drape, a midline incision was made through the abdominal wall. The terminal ileum was delivered and homogenate injected intramurally with a 30 gauge needle, circumferentially at a point $1 \mathrm{~cm}$ from the ileocaecal valve. Homogenates from a single source were injected into individual animals, with the exception of the experiments performed on rabbits. In these experiments, each rabbit received homogenates obtained from two different patients with Crohn's disease. One homogenate was injected into multiple sites in the terminal ileum, the other into multiple sites in the appendix. Material from six patients with Crohn's disease was used in this part of the study. Finally, the bowel was returned to the abdominal cavity and the incision closed with continuous catgut sutures and skin clips.

\section{LYMPHATIC OBSTRUCTION}

\section{Footpad}

Nineteen rats underwent regional lymphadenectomy and ligation of the draining lymph trunk before the inoculation of homogenates. Rats which were to receive footpad inoculation of Crohn's homogenates into the plantar aspect of each footpad were injected with $0.03 \mathrm{ml}$ of methylene blue dye into the dorsum of the foot. The popliteal node was removed and the inguinal region was then explored. Inguinal nodes were removed and draining lymphatics about the femoral vessels identified using a Zeiss operating microscope and ligated with $7 \cdot 0$ silk.

\section{Ileum}

Fourteen rats which were to receive bowel inoculations of tissue homogenates as above were subjected to the following procedure. The mesenteric lymphatics draining the region were identified using the dissecting microscope and ligated twice, adjacent to the bowel wall and proximal to the draining lymph nodes. In addition, surgical excision of the mesenteric lymph nodes was performed and the intestinal lymphatic trunk ligated. We have previously demonstrated that this procedure produces lymphangiographic and pathological changes indicative of lymphatic obstruction. The homogenates were then injected into the bowel wall as previously described.

\section{GASTROINTESTINAL ADMINISTRATION}

An infant-sized nasogastric tube was passed without anaesthesia in 16 rats and $2 \mathrm{ml}$ of the pooled homogenate injected into the stomach. The homogenate was given daily for six weeks and then once a week for a further six weeks. All of the rats received Crohn's homogenate. Rats were sacrificed at intervals following the administration of homogenate and sections of terminal ileum, colon, 
mesenteric lymph nodes, liver and spleen examined histologically.

PATHOLOGICAL EXAMINATIONS

Animals were sacrificed at intervals up to 455 days. Biopsies of the sites of inoculation were performed as well as full postmortem examination. The terminal ileum was examined histologically in animals receiving only footpad inoculations, as well as those receiving direct inoculations. Tissue sections were stained with haematoxylin and eosin and examined without knowledge of the type of homogenate which had been injected or which operative procedure had been performed. Several sections were examined in each biopsy.

Similar criteria to those described by Mitchell and Rees (1970) were used to assess dermal and intestinal responses. A positive response comprised focal sarcoid-like granulomas consisting of epitheloid cells, giant cells, either Langhan's or foreign-body type, and admixed lymphocytes. For an equivocal response, the requirements were focal and/or diffuse collections of macrophages with foamy cytoplasm without giant cells. A negative response covered a variety of microscopic findings, including acute and chronic inflammation, foreign-body granulomas, postinflammatory fibrosis and normal tissues.

\begin{tabular}{|c|c|c|c|c|c|c|c|c|}
\hline \multicolumn{3}{|c|}{$\begin{array}{l}\text { Animals and Time of } \\
\text { Biopsy (days) }\end{array}$} & \multicolumn{6}{|c|}{ Type of Homogenate } \\
\hline & & & \multicolumn{3}{|c|}{ Crohn's } & \multicolumn{3}{|c|}{ Control } \\
\hline & & & + & \pm & - & + & \pm & - \\
\hline Mice & $\begin{array}{l}\text { Early } \\
\text { Late }\end{array}$ & $\begin{array}{l}(186) \\
(455)\end{array}$ & $\begin{array}{l}0 \\
0\end{array}$ & $\begin{array}{l}0 \\
0\end{array}$ & $\begin{array}{l}6 \\
3\end{array}$ & $\begin{array}{l}0 \\
0\end{array}$ & $\begin{array}{l}0 \\
0\end{array}$ & $\begin{array}{l}6 \\
2\end{array}$ \\
\hline Rats & $\begin{array}{l}\text { Early } \\
\text { Late }\end{array}$ & $\begin{array}{l}(50-200) \\
(450)\end{array}$ & $\begin{array}{l}0 \\
0\end{array}$ & $\begin{array}{l}0 \\
0\end{array}$ & $\begin{array}{l}3 \\
4\end{array}$ & $\begin{array}{l}0 \\
0\end{array}$ & $\begin{array}{l}0 \\
0\end{array}$ & $\begin{array}{l}7 \\
4\end{array}$ \\
\hline \multicolumn{2}{|c|}{ Rabbits } & $(154-273)$ & 0 & 0 & 7 & - & - & - \\
\hline
\end{tabular}

Table II Animals with bowel injection and no lymphatic obstruction

$+=$ positive, $\pm=$ equivocal, $-=$ negative

\begin{tabular}{|c|c|c|c|c|c|c|}
\hline \multirow{3}{*}{$\begin{array}{l}\text { Animals, Sites of } \\
\text { Inoculation, and Times of } \\
\text { Biopsy (days) }\end{array}$} & \multicolumn{6}{|c|}{ Type of Homogenate } \\
\hline & \multicolumn{3}{|c|}{ Crohn's } & \multicolumn{3}{|c|}{ Controls } \\
\hline & + & \pm & - & + & \pm & - \\
\hline \multicolumn{7}{|l|}{ Rats (Footpad) } \\
\hline Early $(50-200)$ & 0 & 0 & 6 & 0 & 0 & 8 \\
\hline Late $(380)$ & 0 & 0 & 16 & 0 & 0 & 8 \\
\hline \multicolumn{7}{|l|}{ (Ileum) } \\
\hline Early $(50-200)$ & 0 & 0 & 2 & 0 & 0 & 2 \\
\hline Late $(380)$ & 0 & 0 & 6 & 0 & 0 & 4 \\
\hline \multicolumn{7}{|l|}{ Rats (Ileum) } \\
\hline Early $(50-200)$ & 0 & 0 & 7 & 0 & 0 & 4 \\
\hline Late $(450)$ & 0 & 0 & 1 & 0 & 0 & 2 \\
\hline
\end{tabular}

Table III Animals with regional lymphatic obstruction $+=$ positive, $t=$ equivocal, $-=$ negative

\begin{tabular}{lllll}
\hline $\begin{array}{l}\text { Time of Biopsy } \\
\text { (days) }\end{array}$ & \multicolumn{3}{c}{ Crohn's Homogenate } \\
\cline { 2 - 4 } & + & \pm & - \\
\hline Early & $(80-160)$ & 0 & 0 & 8 \\
Late $\quad(160-250)$ & 0 & 0 & 8 \\
\hline
\end{tabular}

Table IV Rats receiving gastrointestinal administration of homogenate

$+=$ positive, \pm = equivocal, - = negative

\section{Results}

These are set out in tables II, III, and IV. No macroscopic evidence of abnormality was seen in any of the 91 animals at postmortem examination, except for the changes attributable to lymphoedema and surgery.

No sarcoid-like granulomas were found in any biopsy, regardless of the time after administration of homogenates, in any of the animals inoculated with Crohn's homogenates.

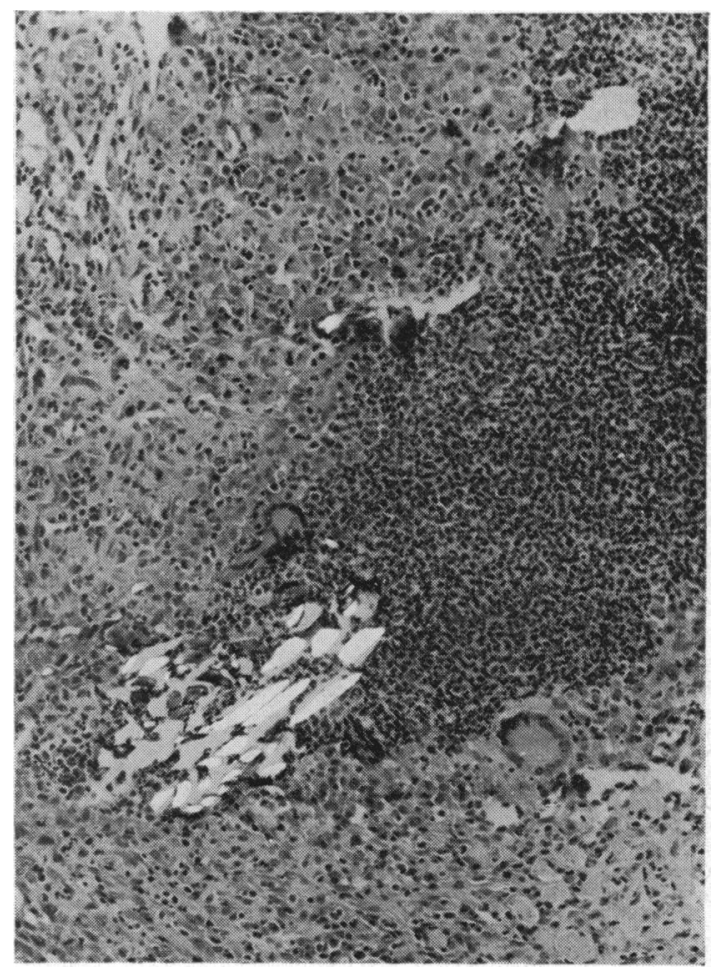

Fig 1 Abscess in omentum with central birefringent foreign material. Adjacent Langhan type giant cells and epitheloid-like macrophages. Ileal injection with control homogenate. Polarized, $H \& E \times 126$ 
Similarly, no granulomas were found in the sites injected with control homogenates.

It is of considerable interest that of all the ileums injected (56) only five showed evidence of mucosal inflammation. In addition, in two of these (mice receiving control homogenates) deposits of amyloid were found in the villi. One animal, which had received control homogenates into the ileum following lymphatic obstruction showed a localized mesenteric abscess containing birefringent foreign material and scanty Langhan's type giant cells (fig 1). The included foreign material, probably keratin, distinguishes this reaction from a true sarcoid type granuloma.

Of 19 injected rat footpads, six showed evidence of chronic inflammation. Three showed foreign-body type giant cell reaction to keratin and hair, and in one of these epitheloid-like cells were also present (fig 2). Again, this is easily distinguished from a sarcoid-like granuloma by the finding of foreign material. The remaining three cases showed scanty foci of macrophages without foreign material.

The results of the microbiological examinations were negative.

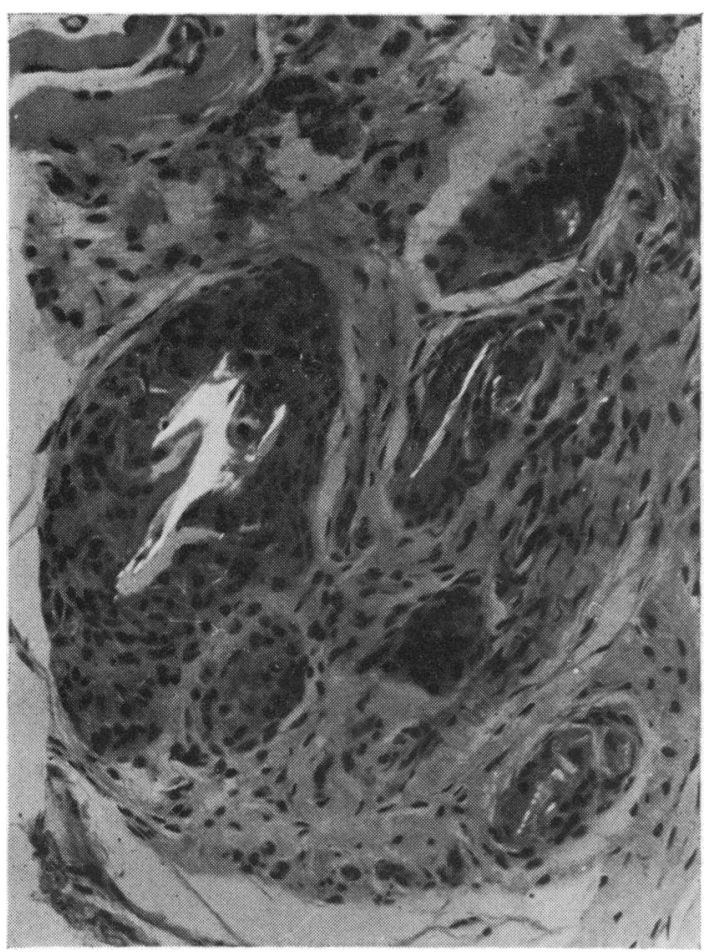

Fig 2 Epitheloid-like macrophage focus around birefringent foreign material within giant cells. Rat footpad injected with control homogenate. Polarized, $H \& E \times 198$

\section{Discussion}

Following our previous inability to confirm the presence of a transmissible agent in Crohn's disease, we have undertaken a further series of animal experiments designed to include several conditions which might be conducive to the demonstration of such an agent The previous reports (Cave et al, 1973; Cave and Mitchell, 1974) showing histological change following intraileal injections of Crohn's tissue in New Zealand white rabbits have not been confirmed nor were any changes demonstrated following intraileal injection in the rats or mice.

Neither lymphatic obstruction nor direct gastrointestinal administration of homogenates was associated with any specific pathologica! changes.

Three successive studies performed by us have failed to confirm the presence of a transmissible agent in Crohn's disease. We have now examined animals of four species, using footpad inoculation and also intraileal injection. We have used normal and immunosuppressed animals, studied inoculation into sites subjected to lymphatic obstruction and investigated the intragastric route of administration. Inoculation of tissue homogenates from 24 patients with Crohn's disease into more than 400 experimental animals has shown no evidence of granuloma formation at the inoculation site. The failure to demonstrate any evidence for a transmissible agent in these studies makes it unlikely for such an agent to be universally present in Crohn's disease and thus to have a significant role in the pathogenesis of this condition.

We would like to thank Mr T. O'Donovan and Mrs G. Elliott for their invaluable assistance.

R.V.H. was in receipt of a clinical research grant from the Welsh Hospital Board.

\section{References}

Ammann, R. W., and Bockus, H. L. (1961). Pathogenesis of regiona enteritis. Arch. intern. Med., 107, 504-513.

Bolton, P. M., Owen, E., Heatley, R. V., Jones Williams, W., and Hughes, L. E. (1973). Negative findings in laboratory animals for a transmissible agent in Crohn's disease. Lancet, 2, 1122-1124.

Bolton, P. M., Heatley, R. V., Owen, E., Jones Williams, W., and Hughes, L. E. (1974). Aetiology of Crohn's disease. Lancet, 2, 951.

Cave, D. R., Mitchell, D. N., Kane, S. P., and Brooke, B. N. (1973) Further animal evidence of a transmissible agent in Crohn's disease. Lancet, 2, 1120-1122.

Cave, D. R., and Mitchell, D. N. (1974). An experimental animal model of Crohn's disease. Gut, $15,345$.

Drinker, C. K., Field, M. E., and Homans, J. (1934). The experimental production of edema and elephantiasis as a result of lymphatic obstruction. Amer. J. Physiol., 108, 509-520.

Dykes, P. W. (1970). Delayed hypersensitivity in Crohn's disease. Proc. roy. Soc. Med., 63, 906-908.

Hadfield, G. (1939). The primary histological lesion of regional ileitis. Lancet, 2, 773-775.

Mitchell, D. N., and Rees, R. J. W. (1970). Agent transmissible from Crohn's disease tissue. Lancet, 2, 168-171. 
Reichert, F. L., and Mathes, M. E. (1936). Experimental lymphedema of the intestinal tract and its relation to regional cicatrizing enteritis. Ann. Surg., 104, 601-616.

Taub, R. N., and Siltzbach, L. E. (1972). Induction of granulomas in mice by injection of human sarcoid and ileitis homogenates.
In Proceedings of the VI International Conference on Sarcoidosis, p. 5 .

Warren, S., and Sommers, S. C. (1954). Pathology of regional ileitis and ulcerative colitis. J. Amer. med. Ass., 154, 189-193. 